\title{
Accounting
}

\section{Institutions, microeconomic factors and stock market capitalization: Evidence from the EAP countries}

\author{
Lai Cao Mai Phuong ${ }^{a^{*}}$
}

${ }^{a}$ Faculty of Finance and Banking, Industrial University of Ho Chi Minh City, Ho Chi Minh, Vietnam

\begin{tabular}{l}
\hline C H R O N I C L E \\
\hline Article history: \\
Received March 102020 \\
Received in revised format March \\
152020 \\
Accepted May 302020 \\
Available online \\
June 12020 \\
\hline Keywords: \\
Institutions \\
Macroeconomic factors \\
Market capitalization \\
East Asian and Pacific countries
\end{tabular}

\section{A B S T R A C T}

\begin{abstract}
The purpose of this study was to examine the influence of institutions and macroeconomic factors on the capitalization of securities in East Asian and Pacific countries (EAP). A balanced panel data is used to collect time-series from 2008 to 2018 in 11 EAP countries and to analyze the impacts of institutions, macroeconomics and stock market capitalization by the general moment method (GMM). Instead of measuring in detail each aspect of the institution as in previous studies, the six institutional aspects as defined by Kaufmann et al. (2011) [Kaufmann, D., Kraay, A., \& Mastruzzi, M. (2011). The worldwide governance indicators: methodology and analytical issues. Hague Journal on the Rule of Law, 3(2), 220-246.] were calculated into one institutional variable. The institutional variables in this article were measured to ensure a more logical and consistent way of institutional influence on stock capitalization. The results indicate that, the institutions and macroeconomic factors were significant in forecasting the stock market capitalization size. Institutional, economic growth and savings had positive effects, macroeconomic factors such as inflation and high interest rates had a negative impact on stock capitalization in EAP countries. The institutions and macroeconomic factors had a significant impact on stock capitalization in EAP countries, the majority of developed markets had better institutions, better control of inflation and interest rates, and most undeveloped markets had higher economic growth and domestic savings.
\end{abstract}

\section{Introduction}

Previous studies on factors affecting stock market capitalization have been carried out separately under two groups of factors: institutional and macroeconomic factors. Early research on institutions affecting the stock market was mainly exploited in a country like Greece by Asteriou and Siriopoulos (2000), in Asia by Gani and Ngassam (2008), and globally by Hooper et al. (2009). The findings of these studies all confirm the important role of institutions in the development of the stock market. Institutional weakness such as political instability (Asteriou \& Siriopoulos, 2000), corruption (Bolgorian, 2011), and ineffective government governance (Gani \& Ngassam, 2008) negatively impact on the development of the stock market. Therefore, improving the quality of institutions in all aspects such as legal, political stability and effective economic management for the stock market to develop sustainably is necessary (Setayesh \& Daryaei, 2017; Hail and Leuz, 2003, Gani \& Ngassam, 2008, Hooper et al., 2009). Previous macroeconomic factors affecting stock markets have mainly focused on industrialized countries (Garcia \& Liu, 1999), ASEAN countries (Wongbangpo \& Sharma, 2002), and other countries in the Middle East and Central

* Corresponding author.

E-mail address: lcmphuong@gmail.com laicaomaiphuong@iuh.edu.vn (L. C. M. Phuong) 
Asia (Billmeier \& Massa, 2009). The findings of these studies suggest that macroeconomic factors such as economic growth, inflation, interest rates, exchange rates are affecting the stock market capitalization (Garcia \& Liu, 1999, Wongbangpo). \& Sharma, 2002, Billmeier \& Massa, 2009, Gan, Yong \& Zhang, 2006). Based on the work of Yartey (2010) this paper examines the influence of institutions and macroeconomic factors on the capitalization of securities in 11 EAP countries from 2008 to 2018. Unlike previous studies, the institutional aspects are aggregated into a single variable, the institutional variable. The results indicate that that institutions, economic growth and savings had positive effects, macroeconomic factors such as inflation and high interest rates had a negative impact on stock capitalization in EAP countries. Among these factors, the institutions that control inflation and interest rates in most developed markets were in better conditions, and the economic growth and domestic savings of most undeveloped markets were higher.

The structure of the paper consists of five sections: Section 1: Introduction, section 2: Literature review, section 3: Methodology and Data, section 4: Results; section 5: Suggestions, and section 6: Conclusion of article.

\section{Literature review}

Institution is defined as the capacity of the government to exercise the power of managing a nation's economic and social resources effectively for development (World Bank, 1992). Kaufmann, Kraay and Mastruzzi (2011) argue that institutions are expressed through power exercised domestically in three respects: The process of government members being monitored, selected and replaced; government capacity in formulating and effectively implementing its reasonable policies; and organizations that earn the respect of citizens and the government in economic and social activities. Scholars can give different definitions of institutions but it is important to understand that no model is the best that can be used for any condition of any country (Saich, 2007). A number of previous studies have concluded that institutions play an important role in the size of stock market capitalization and the development of the stock market. Political instability (Asteriou \& Siriopoulos, 2000), poor quality of regulation and ineffective government governance (Gani \& Ngassam, 2008), and corruption (Bolgorian, 2011) all have a negative impact on the development of the stock market. Because of weak national institutions, the average cost of capital of firms is higher (Hail \& Leuz, 2003), both the stock market risk and the idiosyncratic risk are higher (Hooper et al., 2009) compared to other good institutional institutions. Therefore, when institutions improve as a strong legal system (Hail \& Leuz, 2003), better corruption awareness and political stability actively support expansion (Gani \& Ngassam, 2008), and improve stock market performance (Hooper et al., 2009). The macroeconomic factors are closely related to the growth and development of the stock market. Garcia and Liu (1999) examined the macroeconomic factors affecting the development of the stock market, especially the market capitalization in 15 industrial countries from 1980 to 1995 . The authors found that real income, high savings rates, development of financial intermediaries and liquidity of the stock market were important factors determining the capitalization of the stock market; Stock market development and financial intermediation development are additions, not replacements. From this result Garcia and Liu (1999) concluded that sustainable economic growth, high savings rates, liquidity stock market and the development of the banking industry are the factors that have supported the stock markets of East Asian countries were more developed than those of Latin American countries during 1980-1995.

Wongbangpo and Sharma (2002) performed an investigation on 5 ASEAN countries based on monthly data over the period 1985-1996, and the results showed that the gross national product had a positive impact on stock prices. However, the direction of the impact of each macro factor on the national stock market was inconsistent. The two authors found a positive correlation between interest rates and stock prices in the Philippines, Singapore and Thailand, but this correlation was negative for Indonesia and Malaysia. High inflation negatively affects stock prices in Indonesia and the Philippines. The exchange rate has a positive effect on stock prices in Indonesia, Malaysia and the Philippines, but negatively impacts stock prices in Singapore and Thailand. Wongbangpo and Sharma (2002) argue that the positive relationship of exchange rates is due to competition in world export markets, while the negative relationship of exchange rates can be proved from the asset point of view of the exchange rate. Gan, Yong \& Zhang (2006) examined the relationship between New Zealand's stock index (NZSE40) and seven macro variables monthly from January 1990 to January 2003. The results show that real money supply and GDP have a positive impact, in contrast, inflation and interest rates have a negative impact on the NZSE40 index. Billmeier and Massa (2009) used fixed-effect regression of panel data for 17 emerging countries in the Middle East and Central Asia, the results show that income and investment (the ratio of gross fixed capital formation), stock liquidity (the percentage of stock trade value relative to GDP), oil prices had positive impacts on stock market capitalization. Inflation, domestic credit, and Federal funds rate do not affect stock market capitalization. Attention to both institutions and macroeconomic factors affecting the size of the stock market was studied by Yartey (2010) for 42 emerging economies from 1990 to 2004. Using the GMM estimation, Yartey (2010) concluded that institutions are an important determinant of the size of the stock market because they enhance the viability of external finance. Macroeconomic factors such as income levels, domestic investment, banking sector development, private capital flows and stock market liquidity are important factors determining the development of the stock market in emerging market countries. Previous studies have shown that institutions and macroeconomic factors are factors affecting the development of the stock market. However, the direction of impact (positive or negative) of these factors to the level of stock capitalization is not 
consistent with all data samples (Wongbangpo \& Sharma 2002, Gan et al., 2006, Gani \& Ngassam, 2008, Billmeier \& Massa, 2009, Bolgorian, 2011).

East Asia and Pacific Region (EAP) are emerging as one of the fastest growing market size markets in the world. During the years of 2008-2018, the percentage of market capitalization relative to GDP of EAP excluding Hong Kong increased from $49.6 \%$ to $86.2 \%$, which is much higher than the global average of $46.0 \%$ to $67.7 \%$. How did institutions and / or macroeconomic factors affect stock market capitalization in this region? Based on the research of Yartey (2010), this paper examines the influence of institutions and macroeconomic factors on stock market capitalization in EAP countries in the period from 2008 to 2018. The eleven EAP countries studied in this article include: Australia, China, Indonesia, Japan, Korea, Malaysia, New Zealand, Philippines, Singapore, Thailand, and Vietnam.

\section{Methodology and Data}

\subsection{The model}

To determine the factors that affect the value of stock capitalization in EAP countries, based on collected data, previous studies and after adjusting some variables compared to Yartey's research (2010), the article of empirical modelling is a function of the form:

where: $\mathrm{t}=\overline{2008-2018} ; \mathrm{i}=\overline{1-11}$.

Dependent variable (MC): stock market capitalization relative to gross domestic product. The independent variables include:

- Economic growth (GDP): Percentage of annual economic growth, base year: 2010,

- Savings (SAV): Domestic savings as a percentage of gross domestic product,

- Inflation (INF): Consumer price index, $2010=100$,

- Interest rate (LEND): The bank interest rate meets the demand for short-term loans to the private sector,

- Development of financial intermediation (CRE): Domestic credit to the private sector as a percentage of gross domestic product,

- Exchange rate (FX): The official exchange rate of the local currency per US dollar,

- Institutional (GQ): Averaged over six aspects, including: voice and accountability, political stability and absence of violence/terrorism, government effectiveness, regulatory quality, rule of law, control of corruption,

- The lag variable of the dependent variable $\left(\mathrm{MC}_{\mathrm{t}-1}\right)$ is also used in the research model to ensure the dynamic concept of the stock market (Yartey, 2010).

Variable names, variable symbols, expected sign of variables, and related previous research in the empirical research model of this paper are detailed in Table 1.

Table 1

Definition, variable symbols, expected sign of variables, and previous studies in the empirical research model

\begin{tabular}{lccl}
\hline \multicolumn{1}{c}{ Variable names } & $\begin{array}{c}\text { Variable } \\
\text { symbols }\end{array}$ & $\begin{array}{c}\text { Expected } \\
\text { sign of } \\
\text { variables }\end{array}$ & \multicolumn{1}{c}{ Previous research } \\
\hline $\begin{array}{l}\text { Dependent variable } \\
\text { Market capitalization }\end{array}$ & MC & & \\
\hline $\begin{array}{l}\text { Independent variables } \\
\begin{array}{l}\text { One lag of the dependent } \\
\text { variable }\end{array}\end{array}$ & MC.11 & + & Yartey (2010) \\
\hline $\begin{array}{l}\text { Macroeconomic factors } \\
\text { Economic growth }\end{array}$ & GDP & + & $\begin{array}{l}\text { Gan et al. (2006), Garcia \& Liu (1999), Wongbangpo \& } \\
\text { Sharma (2002) }\end{array}$ \\
\hline Inflation & INF & - & Gan et al. (2006), Wongbangpo \& Sharma (2002) \\
\hline Interest rates & LEND & - & \\
\hline Exchange rate & FX & - & Wongbangpo \& Sharma (2002), \\
\hline $\begin{array}{l}\text { Development of financial } \\
\text { intermediaries }\end{array}$ & CRE & + & $\begin{array}{l}\text { Garcia \& Liu (1999), } \\
\text { Yartey (2010) }\end{array}$ \\
\hline Saving & SAV & - & Garcia \& Liu (1999) \\
\hline Institutions & GQ & + & Author's calculations \\
\hline
\end{tabular}


To achieve the goal of the study, the research data, that are investigated in 11 EAP countries, including Australia, China, Indonesia, Japan, Korea, Malaysia, New Zealand, Philippines, Singapore, Thailand, and Vietnam, are collected from 2008 to 2018. According to the Morgan Stanley Capital International ${ }^{1}$ classification in the research countries there are four developed markets (Australia, Japan, New Zealand, Singapore), six emerging markets (China, Indonesia, Korea, Malaysia, Philippines, Thailand) and Vietnam frontier market. In the sample, there are three developed economies, Australia, Japan, and New Zealand, and the remaining eight are developing economies (Drysdale, 2018). Vietnam was selected in this study due to its close political, economic and capital markets linkages with the remaining countries. Vietnam is a member of ASEAN along with Indonesia, Malaysia, Philippines, Singapore and Thailand. Here the process of building the ASEAN capital market is underway. At the same time, Vietnam is also part of the Comprehensive and Progressive Agreement for Trans-Pacific Partnership along with Australia, Japan, Singapore and New Zealand. The difference from previous published studies on the influence of institutions on market capitalization is the method of measuring the institutional variation. Studies of Asteriou \& Siriopoulos (2000), Hail and Leuz (2003), Gani \& Ngassam (2008), Hooper et al (2009), Yartey (2010), Bolgorian (2011) all used institutional variants individual aspects. However, it is important to understand that a well-institutionalized state must sum up all the individual aspects. In fact, there are studies that find out that the impact of institutions on the stock market is negative (for example, corruption in Bolgorian, 2011), but there are no studies suggesting that institutions should not be improved. Therefore, this study uses an institutional variable that is the combined value of six individual institutional aspects published by The Worldwide Governance Indicators. This method of measuring institutional variation in this way has two advantages compared to previous studies. Firstly, institutional variation is the result of many aspects related to institutions, so it is more representative. Second, it also ensures more logical and consistent arguments in the case of institutional aspects that give conflicting effects on stock capitalization. In order to eliminate differences in economic capacities between countries, variables including stock market capitalization (MC), development of financial intermediaries (CRE), domestic savings (SAV) are calculated. as a percentage of gross domestic product. The economic growth (GDP) and inflation (INF) variables were used based on 2010. The institutional variable $(\mathrm{QG})$ is the average of the six individual institutional aspects published by The Worldwide Governance Indicators. Except for the GQ variable, all remaining variables in the model are converted to log data when used in the research model. GQ variable data is aggregated from The Worldwide Governance Indicators ${ }^{2}$. Macroeconomic data and stock market capitalization data are collected from the World Bank ${ }^{3}$.

\subsection{Estimation method}

The data set, that is collected from 2008 to 2018, is a time series and hence the applied panel data estimation techniques in the regression model fit this research. To avoid endogeneity between variables in the model and eliminate heteroscedasticity of residuals, this article uses the generalized method of moments (GMM) of Hansen (1982) under moment conditions proposed by Ahn and Schmidt (1995) to estimate panel data. The instrument variables used are lagged values of all endogenous regressors. Post-estimation tests such as Arellano and Bond test of autocorrelation (Arellano and Bond, 1991), testing of Sargan's (1958) overidentifying restrictions to ensure the estimation method is consistent with the model.

\section{Results}

Overall, China, Malaysia and Singapore are three countries with many variables (5/8 variables) better value than the average of 11 countries. In contrast, Vietnam was the only country whose GDP was better than average. This is appropriate because the level of development of Vietnam's stock market is the lowest compared to the remaining 10 countries.

Stock market capitalization (MC): Singapore (221.8), Malaysia (132.5), Australia (97.5), and Korea (89.1) are the four countries with a higher capitalization value than the average, three countries have the lowest values include Indonesia (42.5), New Zealand (34.4) and Vietnam (31.7). It clearly indicates that most developed markets have a higher market capitalization (except New Zealand) than emerging markets (except Malaysia) and the marginal markets.

Institutions (GQ): Four countries including New Zealand (1.81), Australia (1.59), Singapore (1.55) and Japan (1.3) with the best institutional quality are all developed markets. On the other side, countries with less than zero institutional variation include China (-0.48), Vietnam (-0.47), Philippines (-0.38), Indonesia (-0.33) and Thailand (-0.3). It can be recognized that developed markets often have superior institutional quality compared to emerging and frontier markets.

\footnotetext{
${ }^{1} \mathrm{https}: / /$ www.msci.com/market-classification

2 http://info.worldbank.org/governance/wgi/

${ }^{3}$ https://data.worldbank.org/indicator.
} 
Economic growth (GDP): In the period of 2008-2018, China and Vietnam were the two countries with the highest annual economic growth rates of 8.1 and 6.1, respectively. In contrast, the economic growth rate in developed economies is much lower, for example for Japan it only averages $0.5 \%$ per year. Except for Korea and Thailand, economic growth in developing economies the rate is higher than average values and higher than developed economies.

Table 2

Statistical average of variables in the model, 2008-2018

\begin{tabular}{llcccccccc}
\hline id & Country & MC $^{\mathrm{a}}$ & GDP $^{\mathrm{a}}$ & SAV $^{\mathrm{a}}$ & CRE $^{\mathrm{a}}$ & INF & FX & LEND $^{\mathrm{a}}$ & GQ $^{2}$ \\
\hline 1 & Australia & 97.5 & 2.7 & 25.9 & 129.6 & 107.1 & 1.2 & 6.4 & 1.59 \\
2 & China & 56.4 & 8.1 & 48.9 & 137.2 & 109.6 & 6.5 & 5.3 & $(0.48)$ \\
3 & Indonesia & 42.5 & 5.4 & 33.4 & 34.0 & 118.3 & $11,270.8$ & 12.4 & $(0.33)$ \\
4 & Japan & 84.3 & 0.5 & 22.9 & 163.1 & 101.9 & 100.0 & 1.4 & 1.30 \\
5 & Korea & 89.1 & 3.1 & 34.7 & 141.4 & 106.1 & $1,130.9$ & 4.8 & 0.78 \\
6 & Malaysia & 132.5 & 4.7 & 35.8 & 114.7 & 108.2 & 3.5 & 4.9 & 0.33 \\
7 & New Zealand & 34.4 & 2.2 & 23.1 & 148.0 & 105.1 & 1.4 & 6.0 & 1.81 \\
8 & Philippines & 75.3 & 5.7 & 16.0 & 40.6 & 109.6 & 46.0 & 6.5 & $(0.38)$ \\
9 & Singapore & 221.8 & 4.4 & 53.0 & 113.7 & 108.1 & 1.3 & 5.4 & 1.55 \\
10 & Thailand & 86.5 & 3.2 & 32.2 & 133.7 & 106.4 & 32.7 & 4.8 & $(0.30)$ \\
11 & Vietnam & 31.7 & 6.1 & 26.6 & 108.6 & 129.2 & $20,364.0$ & 10.6 & $(0.47)$ \\
\hline & Average & 86.5 & 4.2 & 32.0 & 115.0 & 110.0 & - & 6.2 & 0.49 \\
\hline
\end{tabular}

Note: ${ }^{a}$ calculated as a percentage.

Average statistics were calculated before logarit conversion data.

Source: Author's calculations.

Savings (SAV): In general, the size of domestic savings in emerging markets is often higher than the average and in developed markets it is often lower than the average. Specifically, the scale of savings in Singapore and China is the largest when reaching 53 and 48.9 respectively. While the rest of the emerging markets have higher than average domestic savings, this value in the Philippines is only 16, which is lower than the average. In addition, this variable of Vietnam and developed markets (except Singapore) is in the range of 22.9-26.6, both lower than the average of 32.0.

The development of financial intermediation (CRE), interest rate (LEND) and inflation (INF): There seems to be a link between the development of financial intermediaries and macroeconomic factors between countries. It implies that Japan, with large domestic credit, is able to provide businesses with low lending rates, whereas, Indonesia's tight domestic credit makes businesses have higher interest rates compared to the rest of the countries. It implies that Japan, with its large domestic credit, can provide businesses with lower lending rates than the rest of the country, in contrast, Indonesia's tight domestic credit capital forces businesses to pay higher interest rates than other countries. Japan, New Zealand, and Korea all have INF below 106.2, while the Philippines, Indonesia, and Vietnam have INF above 109.5, showing that developed countries often control inflation better than developing countries. The SAV ranges from 16-53, of which the SAV of Singapore is the highest and the SAV of the Philippines is the lowest. The results of the research model of the impact of institutions and macroeconomic factors on the capitalization of securities in 11 EAP countries are reported in Table 3. Arellano-Bond's test results for residual autocorrelation and Sargan tests tend to support the GMM estimation model.

In this section, the paper combines both the analysis of research results and discussion of research findings.

GDP variable: Economic growth in developing economies in the sample is all higher than developed economies (Table 2). The GDP variable has a regression coefficient greater than zero with a statistical significance of 5\%, showing that economic growth has a positive impact on the size of stock capitalization (Table 3). This means that rapid economic growth creates confidence and expectations for investors about the prospects of the economy and the stock market in the future, which is a good condition to increase the value of stock capitalization. This result is consistent with the studies of Garcia \& Liu (1999), Wongbangpo \& Sharma (2002), Gan et al. (2006).

The variable INF is statistically significant at $5 \%$ and the negative regression coefficient indicates that inflation has a negative impact on stock capitalization. This finding is different from the results of Billmeier \& Massa (2009) in the Middle East and Central Asian countries, supporting the research of Wongbangpo \& Sharma (2002), Gan et al. (2006). High inflation increases costs, erodes corporate profits thereby negatively impacting on company valuations, leading to a decline in stock market capitalization. The statistical analysis in Table 2 shows that developed economies and Korea have better control of inflation 
than the rest. Indonesia and Vietnam are the two developing economies with the highest inflation in the sample when the annual average value reaches double digits.

The variable LEND has a negative regression coefficient, which indicates that interest rates harm capitalization with a statistical significance of 5\%. This finding supports the research of Wongbangpo and Sharma (2002) in Indonesia and Malaysia and Gan et al. (2006) in New Zealand, but different from the results of Billmeier \& Massa (2009) when the two authors could not find the impact of interest rates on market capitalization in the Middle East and Central Asia. Increased interest rates directly affect the costs of businesses, increasing costs for securities investors using loans. As a result, businesses face the possibility of reducing profits and making them consider more carefully with the expansion of production, investors are more cautious when participating in the stock have to recalculate profits due to increased costs. Therefore, stock capitalization has declined as interest rates increased. Similar to inflation, the average annual interest rate during the research period in Indonesia, Vietnam is also very high among the research countries, reaching $12.4 \%$ and $10.6 \%$ respectively.

\section{Table 3}

Regression results of institutional and macroeconomic impacts on stock market capitalization at EAP

\begin{tabular}{lccc}
\hline MC & Coef. & $\mathrm{Z}$ & $\mathrm{P}>\mathrm{Z}$ \\
\hline MC.11 & 0.2661 & 0.75 & 0.452 \\
GDP & $0.5161^{* * *}$ & 2.59 & 0.010 \\
SAV & $6.1969^{* * *}$ & 2.89 & 0.004 \\
CRE & -0.1576 & -0.11 & 0.914 \\
INF & $-2.5316^{* *}$ & -1.99 & 0.047 \\
FX & 0.4562 & 1.04 & 0.298 \\
LEND & $-3.0995^{* *}$ & -2.21 & 0.027 \\
GQ & $1.3132^{*}$ & 1.67 & 0.094 \\
cons & $-8.4009^{* * *}$ & -2.78 & 0.005 \\
\hline N & 110 & & \\
\hline Arellano-Bond test for autocorrelation of the first-differenced residuals & & \\
$1^{\text {st }}$ order autocorrelation & -0.7937 & 0.4276 \\
$2^{\text {nd }}$ order autocorrelation & 1.5607 & 0.1186 \\
\hline Sargan test of the overidentifying restrictions & & \\
1-step weighting matrix & 2.0991 & 0.9997 \\
2-step weighting matrix & 11.0000 & 0.9899 \\
\hline
\end{tabular}

Note: *,** and *** indicate significance at the $10 \%, 5 \%$, and $1 \%$ level, respectively.

Source: Calculated by the author.

SAV variable: Regression coefficient of domestic saving variable is greater than zero with a $1 \%$ significance level, showing that this variable has a positive impact on the stock market capitalization (Table 3). This finding is true for the EAP region, which includes many economies with different levels of development, not only for developed countries as in the research of Garcia \& Liu (1999). The statistical analysis also shows that emerging markets, except the Philippines, have larger savings than other markets (Table 2). The large scale of domestic savings is a potential financial source for the stock market. When the profitability opportunities in the stock market become more attractive, a part of the savings is transferred to investment. The addition, financial resources create an impetus for the increase in market capitalization.

GQ variable: Results of Table 3 indicate that institutions had a positive impact on stock market capitalization at the 10\% significance level. This finding supports studies of Hail and Leuz (2003), Gani \& Ngassam (2008), Hooper et al. (2009), Yartey (2010). Developed markets often have significantly better institutions than underdeveloped markets (Table 2). It must ensure that the government has a rational and effective implementation of its policies, political stability, respect for people's feedback, compliance with laws and control of corruption.

\section{Suggestions}

Institutions, economic growth, savings, inflation and interest rates are factors that affect the stock market capitalization in 11 EAP countries. In order to increase the scale of sustainable stock market capitalization in each country, the positive factors that need to be improved are institutions, economic growth and savings, while limiting the negative impacts from inflation and interest. The analysis shows that most developed economies have better institutions than developing ones. Singapore and Malaysia are respectively the countries with the highest and second highest capitalization rates among the 11 countries studied. These are also two countries with the majority of variables better than the other countries in the sample. Therefore, in order to 
increase sustainable stock capitalization in developing economies, research considerations should be based on experiences from Singapore, Malaysia, and developed economies to apply appropriately for each economy.

\section{Conclusion}

The study has aimed to determine the influence of institutions and macroeconomic factors on the capitalization of 11 EAP countries. The study has used GMM estimates on balance panel data from 2008 to 2018. The independent variables used in the model include economic growth, savings, development of financial intermediaries, inflation, lending rates, exchange rates and institutions. Unlike previous studies that used each aspect of the institution, this paper has measured each country's institutional variation as a composite index of six individual institutional aspects. The results have shown that economic growth, savings, institutions had a positive impact on the capitalization of securities. In contrast, high inflation and high lending rates negatively impact on the market capitalization. From this result, countries need to improve institutional quality, control inflation and interest rates, promote economic growth, increase savings rates to expand sustainable stock market capitalization.

\section{Acknowledgement}

The author would like to thank to anonymous referees for construction comments on earlier version of this paper.

\section{References}

Ahn, S. C., \& Schmidt, P. (1995). Efficient estimation of models for dynamic panel data. Journal of econometrics, 68(1), 5-28.

Arellano, M., \& Bond, S. R. (1991). Some tests of specification for panel data: Monte Carlo evidence and an application to employment equations. Review of Economic Studies, 58(2), 277-297.

Asteriou, D., \& Siriopoulos, C. (2000). The role of political instability in stock market development and economic growth: The case of Greece. Economic Notes, 29(3), 355-374.

Billmeier, A., \& Massa, I. (2009). What drives stock market development in emerging markets-institutions, remittances, or natural resources? Emerging Markets Review, 10(1), 23-35.

Bolgorian, M. (2011). Corruption and stock market development: A quantitative approach. Physica A: Statistical Mechanics and its Applications, 390(23-24), 4514-4521.

Drysdale, C. (2018). World Economic Situation and Prospects 2018. New York: United Nations Department of Economic and Social Affairs.

Gan, C., Lee, M., Yong, H. H. A., \& Zhang, J. (2006). Macroeconomic variables and stock market interactions: New Zealand evidence. Investment Management and Financial Innovations, 3(4), 89-101.

Gani, A., \& Ngassam, C. (2008). Effect of institutional factors on stock market development in Asia. American Journal of Finance and Accounting, 1(2), 103-120.

Garcia, V. F., \& Liu, L. (1999). Macroeconomic determinants of stock market development. Journal of Applied Economics, 2(1), 29-59.

Hail, L., \& Leuz, C. (2006). International differences in the cost of equity capital: Do legal institutions and securities regulation matter? Journal of Accounting Research, 44(3), 485-531.

Hansen, L. P. (1982). Large sample properties of generalized method of moments estimators. Econometrica: Journal of the Econometric Society, 1029-1054.

Hooper, V., Sim, A. B., \& Uppal, A. (2009). Governance and stock market performance. Economic Systems, 33(2), 93-116.

Kaufmann, D., Kraay, A., \& Mastruzzi, M. (2011). The worldwide governance indicators: methodology and analytical issues. Hague Journal on the Rule of Law, 3(2), 220-246.

Saich, T. (2007). China in 2006: focus on social development. Asian Survey, 47(1), 32-43.

Setayesh, M. H., \& Daryaei, A. A. (2017). Good governance, innovation, economic growth and the stock market turnover rate. The Journal of International Trade \& Economic Development, 26(7), 829-850.

Sargan, J. D. (1958). The estimation of economic relationships using instrumental variables. Econometrica, $26(3), 393-415$.

Wongbangpo, P., \& Sharma, S. C. (2002). Stock market and macroeconomic fundamental dynamic interactions: ASEAN-5 countries. Journal of Asian Economics, 13(1), 27-51.

World Bank. (1992). Govemance and Development. The World Bank. Washington, D.C. ISBN 0-8213-2094-7.

Yartey, C. A. (2010). The institutional and macroeconomic determinants of stock market development in emerging economies. Applied Financial Economics, 20(21), 1615-1625. 
(C) 2020 by the authors; licensee Growing Science, Canada. This is an open access article distributed under the terms and conditions of the Creative Commons Attribution (CC-BY) license (http://creativecommons.org/licenses/by/4.0/). 